\title{
Complex of Natural Enemies Associated With Scale Insects (Hemiptera: Coccomorpha) on Sugarcane in Brazil
}

\author{
Maiara A. Cruz ${ }^{1}$, Ana Lúcia B. G. Peronti ${ }^{1}$, Nilza M. Martinelli ${ }^{1}$, Valmir A. Costa ${ }^{2}$, Gabriela P. Ignácio ${ }^{3}$ \\ \& Lucia M. de Almeida ${ }^{4}$ \\ ${ }^{1}$ Faculdade de Ciências Agrárias e Veterinárias, Universidade Estadual Paulista "Júlio de Mesquita Filho", \\ Jaboticabal, SP, Brazil \\ ${ }^{2}$ Centro Avançado de Pesquisa em Proteção Fitossanitária e Saúde Animal, Instituto Biológico, Brazil \\ ${ }^{3}$ Universidade de São Paulo, Ribeirão Preto, SP, Brazil \\ ${ }^{4}$ Universidade Federal do Paraná, Curitiba, PR, Brazil \\ Correspondence: Maiara A. Cruz, Departamento de Fitossanidade, Faculdade de Ciências Agrárias e \\ Veterinárias, Universidade Estadual Paulista "Júlio de Mesquita Filho", Via de acesso Prof. Paulo Donato \\ Castellane, s/n, 14884-900, Jaboticabal, São Paulo, Brazil. Tel: 55-163-209-7311. E-mail: \\ maiara_agronomia@hotmail.com
}

Received: December 4, 2018

Accepted: January 11, 2019 Online Published: March 15, 2019

doi:10.5539/jas.v11n4p160

URL: https://doi.org/10.5539/jas.v11n4p160

\begin{abstract}
A survey of the natural enemies of Aclerda takahashii (Kuwana, 1932) (Hemiptera: Aclerdidae) and Saccharicoccus sacchari (Cockerell, 1895) (Hemiptera: Pseudococcidae) was carried out in the state of São Paulo, Brazil. A total of ten associations were recorded, six parasitoid-host and four predator-prey, which three are new: parasitoids of the genus Eurytoma (Hymenoptera: Eurytomidae) and Hambletonia (Hymenoptera: Encyrtidae) associated with A. takahashii and S. sacchari, respectively; and the predator of the genus Diadiplosis (Diptera: Cecidomyiidae) with a S. sacchari. Anagyrus saccharicola Timberlake, 1932 and Mariola flava Noyes, 1980 (Hymenoptera: Encyrtidae) are reported for the first time in Brazil.
\end{abstract}

Keyswords: ecological interactions, parasitoids, predators, São Paulo state

\section{Introduction}

Aclerda takahashii (Kuwana, 1932) (Hemiptera: Aclerdidae) from the Oriental region is currently distributed in 13 countries, mainly of the Oriental and Paleartic regions. In South America was reported only in Brazil. Saccharicoccus sacchari (Cockerell, 1895) (Hemiptera: Pseudococcidae), with unknown origin, has been reported from most cane growing nation of the world, 72 countries of which eight in South America (Wyckhuys, Kondo, Herrera, Miller, Naranjo, \& Hyman, 2013; García Morales, Denno, Miller, Miller, Ben-Dov, \& Hardy, 2016). Both are monophagous species associated with a small number of host plants of Poaceae (García Morales et al., 2016).

Probably due to the greater distribution and frequency of $S$. sacchari around the world, damages and losses in sugarcane crops infested by this mealybug has been better studied as: delay in plant growth and death of sprouts by Barreto (1932) and Puttarudriah (1954) in sugarcane plantations located in India and Cuba, respectively; and reduction of stem height and diameter with consequent loss in sugar level by Gamal El-Dein, Mohamed Sanaa, Ibrahim, and Fatma (2009), in Egypt. In addition, S. sacchari has been mentioned as transmitting the sugarcane bacilliform virus (SCVB) and Sugarcane mild mosaic virus (SCMMV), detected in cane fields located in Australia, Colombia, Madagascar, Madeira, Malawi, Mauritius, Morocco, Papua New Guinea, South Africa, Taiwan and the USA by Lockhart, Autrey, and Comstock (1992), Autrey, Boolell, Lockhart, Jones, and Nadif (1995), and Victoria, Avellaneda, Angel, and Guzmán (2005).

Females of scale insect in general are the main responsible for the damage to their host plants because they feed on them throughout all instars; while males feed only during the first and second instars (Gullan \& Kosztarab, 1997). Saccharicoccus sacchari may reproduce either bisexually or parthenogenetically (Vichanco \& Villanueva, 1932; Beardsley, 1962). The number of instar obtained by Vichanco and Villanueva (1932) in Philippines, Hafez, and Salama (1969) in Egypt and Girón, Lastra, Gómez, and Mesa (2005) in Colombia, were variable, 3-7 for 
female and 4-5 for males. The occurrence of polymorphism in males of this mealybug was reported by Hafez and Salama (1967), with apterous, winged and intermediate forms. In laboratory conditions in Egypt, only sexual reproduction was observed, with four to five generations per year (Hafez \& Salama, 1969). For A. takahashii this information is unknown.

In Brazil, sugarcane scale insects, especially $S$. sacchari, have been considered as emergent pests, since sugarcane infestation by this mealybug has been reported frequently by producers (Personal communication, Modesto Barreto). However, the increase of population of this mealybug may be related to the changes in the management of the sugarcane fields in the state of São Paulo. Burning the mature crops of sugarcane was practiced for centuries in Brazil but, currently this management has been substituted by the unburned harvest. In addition, a straw cover, consisting by dried leaves and stalks, probably also contributes for the presence of these insects in the field.

Sacharicoccus sachari and A. takahashii settle under overlapping leaf sheaths just below the nodes, which hinders the chemical control (Alam, 1972; Stocks, 2016). In underground S. sacchari infests roots and newly planted seed cane facilitating their spread throughout the area during planting (Beardsley, 1960). The use of insecticides in seed is possible, but considered economically impracticable. Effective control could be achieved through cultural practices and biological control (Rajendra, 1974).

Associated with $S$. sacchari and A. takahashii, 37 species of predators and 45 species of parasitoids (Appendix A) were registered globally. These predators are larvae or adults of Coccinellidae and Staphylinidae (Coleoptera), larvae of Chrysopidae (Neuroptera), Cecidomyiidae, Drosophilidae and Phoridae (Diptera), earwigs of families Forficulidae and Labiduridae (Dermaptera), bedbugs of the families Anthocoridae and Geocoridae (Hemiptera) and microlepdopterous of the families Pyralidae and Momphidae (Lepidoptera), commonly found feeding on eggs, nymphs and adults of coccoids. Parasitoids belong to the families Aphelinidae, Encyrtidae, Pteromalidae, and Signiphoridae (Hymenoptera: Chalcidoidea) are among the most important groups of natural enemies of these scale insects (Noyes, 2017) (Appendix A). In Brazil, natural enemies associated with sugarcane scale insects were recorded mainly by Lima (1935), and De Santis (1972).

The survey of natural enemies, especially of well-established native or exotic species, associated with insects of agricultural importance in a given region is an important instrument for IPM (Integrated Pest Management). In state of São Paulo despite the apparent increase in the populations of scale insects infesting the crop the possible natural enemies associated with them are unknown. The objective of this study was to survey species of natural enemies associated with S. sacchari and A. takahashii, in São Paulo sugarcane plantations; checking the occurrence of natural enemy known in other countries, and to reporting new associations.

\section{Material and Methods}

\subsection{Collect of Biological Material}

The samplings of the natural enemies were carried out in sugarcane plants between August 2016 and August 2017, monthly, in 17 sampling points distributed in nine municipalities, from four mesoregions of the state of São Paulo: (1) Jales, (1) Fernandópolis, (1) Nova Aliança, (1) Pindorama and (1) Votuporanga-mesoregion of São José do Rio Preto; (1) Guariba and (7) Jaboticabal-mesoregion of Ribeirão Preto; (3) São Carlos-mesoregion of São Carlos; and, (1) Campinas-mesoregion of Campinas.

The scale insects and their respective natural enemies were randomically collected from infested sugarcane plants: (A) in small clumps located in backyards and farms, and in the (B) sugarcane field edges.

\subsection{Obtaining Natural Enemies}

Infested nodes were inspected visually mainly in looking for immature predators. Coccinellids and dipterous larvae obtained were placed in transparent plastic pots $(16 \times 12 \times 5 \mathrm{~cm}$ in size $)$, covered with muslin netting and fed with nymphs of the scale insect in which they were found associated on the sugarcane field. The adult predators emerged or collected manually on the colonies of scale insects were posteriorly pinned.

Parasitoids were obtained from ten adults of each scale insects sampled. The scale insects were placed in glass tubes partially covered with laminated paper and closed with plastic film, according to methodology adapted from Prado, Alvarenga, and Santa-Cecília (2015). At $48 \mathrm{~h}$ the emerging adult parasitoids were transferred to 2 $\mathrm{mL}$ eppendorf and preserved in 100\% ethanol. Subsequently, they were fixed on entomological pins. The procedures were performed under controlled conditions $\left(25 \pm 2{ }^{\circ} \mathrm{C}\right.$, photoperiod of $12 \mathrm{~h}$ and UR $\left.65 \pm 5 \%\right)$, in B.O.D. 


\subsection{Slide-Mounted Procediments for the Scale Insects}

Some specimens of coccoids of each sample previously preserved in $75 \%$ ethanol were mounted on microscopic slides following the method described by Granara de Willink (1996). Posteriorly, they were identified according to morphological characteristics of the adult female as described by Mcconnell (1954) for Aclerdidae and Williams and Granara de Willink (1992) for Pseudococcidae.

\subsection{Identification of Natural Enemies}

The parasitoids were identified by the fourth author (VAC), using: Noyes and Hayat (1994); Noyes (1980, 2000); Sharkov (1996); Sharkov and Woolley (1997) and De Santis (1964) to Encyrtidae and DiGiulio (1997) to Eurytomidae. The Drosophilidae were identified by the fifth author (GPI), to genus level using Grimaldi (1990) and to species level using Malogolowkin (1946); by (DCA), using Brown (2010) to Phoridae; by (MVUG), using Gagné (1994); Culik and Ventura (2013) to Ceccidomyiidae, and by the sixth author (LMA), using Gordon $(1985,2008)$ to Coccinellidae.

\subsection{Storage of Voucher Species}

Specimens "voucher" were deposited in the following institutions: the scale insects in the Reference Collection of Insects and Mites (CRIA) of the Plant Protection Department of FCAV/UNESP-Jaboticabal, SP; the parasitoids, in the "Oscar Monte" Entomophagous Insects Collection (IB-CBE) of the Biological Institute of Campinas, SP; the Coccinelidae, in the Entomological Collection Padre Jesus Santiago Moure (DZUP-Department of Zoology, Federal University of Paraná) in Curitiba, PR; in the Museum of Zoology of the University of São Paulo (MZUSP), SP and the drosophilids in the Reference Collection of Insects and Mites (CRIA) of the Plant Protection Department of FCAV/UNESP-Jaboticabal, SP.

\section{Results and Discussion}

\subsection{Identification}

The scale insects collected on nods of sugarcane plants in the state of São Paulo were confirmed as $S$. sacchari and A. takahashii. A total of 394 specimens of natural enemies associated with them were collected in the 17 sampled sites: five per both species, seven to S. sacchari and five to A. takahashii (Appendix B). The natural enemies complex associated with the sugarcane scale insects obtained includes six species of hymenopterous parasitoids and four species of predators (Table 1). 
Table 1. Natural enemies associated with Aclerda takahashii (Kuwana, 1932) and Saccharicoccus sacchari (Cockerell, 1895) collected in the state of São Paulo in the present study, frequent prey and hosts and references

\begin{tabular}{|c|c|c|c|c|}
\hline \multirow{2}{*}{ Natural Enemies } & \multicolumn{3}{|c|}{ Scale insect/frequent prey and hosts } & \multirow{2}{*}{ References } \\
\hline & $A$ & $S$ & Frequent prey and hosts & \\
\hline \multicolumn{5}{|l|}{ COLEOPTERA } \\
\hline \multicolumn{5}{|l|}{ Coccinelidae } \\
\hline ***Hyperaspis sp. & & $\times$ & $\begin{array}{l}\text { Pseudococcidae, Coccidae } \\
\text { and Ortheziidae }\end{array}$ & $\begin{array}{l}\text { (Alam, 1972; Gordon, 1985; Sullivan, Castillo, \& Bellotti, 1991; } \\
\text { Almeida \& Vitorino, 1997; Vandenberg, 2002; Majka \& } \\
\text { Robinson, 2009; González \& Gordon, 2009) }\end{array}$ \\
\hline \multicolumn{5}{|l|}{ DIPTERA } \\
\hline \multicolumn{5}{|l|}{ Cecidomyiidae } \\
\hline ****Diadiplosis sp. & & $\times$ & $\begin{array}{l}\text { Aleyrodidae, Pseudococcidae } \\
\text { and Coccidae }\end{array}$ & $\begin{array}{l}\text { (Harris, 1968; Culik \& Ventura 2009; Gagné, 2010; Culik \& } \\
\text { Ventura, 2012; Culik \& Ventura, 2013) }\end{array}$ \\
\hline \multicolumn{5}{|l|}{ Drosophilidae } \\
\hline $\begin{array}{l}\text { *Rhinoleucophenga obesa } \\
\text { (Loew, 1872) }\end{array}$ & $\times$ & & Aclerdidae & (Lima, 1935; Malogolowkin, 1946; De Santis, 1972) \\
\hline \multicolumn{5}{|l|}{ Phoridae } \\
\hline$* * *$ Megaselia $\mathrm{sp}$ & & $\times$ & Apidae and Ixodidae & $\begin{array}{l}\text { (Rajendra, 1974; Andreotti et al. 2003; Liu, Zhou, Dai, \& Zhang, } \\
\text { 2014) }\end{array}$ \\
\hline \multicolumn{5}{|l|}{ HYMENOPTERA } \\
\hline \multicolumn{5}{|l|}{ Encyrtidae } \\
\hline $\begin{array}{l}\text { **Anagyrus saccharicola } \\
\text { Timberlake, } 1932\end{array}$ & & $\times$ & Pseudococcidae + & $\begin{array}{l}\text { (Carver, Inkerman, \& Ashbolt, 1987; Noyes, 2017; García } \\
\text { Morales, Denno, Miller, Miller, Ben-Dov, \& Hardy, 2016) }\end{array}$ \\
\hline $\begin{array}{l}\text { *Mucrencyrtus aclerdae } \\
\text { (De Santis, 1972) }\end{array}$ & $\times$ & & Aclerdidae & (De Santis, 1972; Culik, Martins, \& Ventura, 2011) \\
\hline **Mariola flava Noyes, 1980 & $\times$ & & Aclerdidae ++ & (Noyes, 2010; Noyes, 2017) \\
\hline ****Hambletonia $\mathrm{sp}$ & & $\times$ & & \\
\hline *Cheiloneurus sp. & $\times$ & & $\begin{array}{l}\text { Secondary parasitic of } \\
\text { various groups of insects }\end{array}$ & (De Santis, 1972; Trjaptizin \& Zuparko, 2004) \\
\hline \multicolumn{5}{|l|}{ Eurytomidae } \\
\hline$* * * *$ Eurytoma $\mathrm{sp}$ & $x$ & & $\begin{array}{l}\text { Secondary parasitic of } \\
\text { various groups of insects }\end{array}$ & (Noyes, 2017) \\
\hline
\end{tabular}

Note. Species of scale insects studied: A: Aclerda takahashii; S: Saccharicoccus sacchari; OH: other hosts. * Species found in the state of São Paulo in the present survey; ** species registered for the first time in Brazil; *** interactions recorded for the first time for Brazil and **** new ecological interactions. + Associated to another species of mealybugs; ++ Associated with several species of Aclerdidae.

\subsection{Natural Enemies of S. sacchari}

From the S. sacchari, the parasitoids emerged were: Anagyrus saccharicola Timberlake, 1932 and Hambletonia sp. (Hymenoptera: Encyrtidae); and obtained the predators Diadiplosis sp. (Diptera: Cecidomyiidae), Megaselia sp. (Diptera: Phoridae), Hyperaspis sp. (Coleoptera: Coccinellidae).

\subsection{Natural Enemies of A. takahashii}

From A. takahashii the parasitoids: Mucrencyrtus aclerdae (De Santis, 1972), Mariola flava Noyes, 1980, Cheiloneurus sp. (Hymenoptera: Encyrtidae) and Eurytoma sp. (Hymenoptera: Eurytomidae); and the predator Rhinoleucophenga obesa (Loew, 1872), (Diptera: Drosophilidae).

\subsection{Associations Reported}

A total of ten associations were recorded, six parasitoid-host and four predator-prey, three of which are new: parasitoids of the genus Eurytoma (Hymenoptera: Eurytomidae) and Hambletonia (Hymenoptera: Encyrtidae) associated with A. takahashii and S. sacchari, respectively; and the predator of the genus Diadiplosis (Diptera: Cecidomyiidae) with a $S$. sacchari. All associations registered during this work are new reports for the state of São Paulo. Anagyrus saccharicola and Mariola flava (Hymenoptera: Encyrtidae) are the first time in Brazil (Table 1). 


\subsection{Most Common Natural Enemies, and Other Comments}

The most frequently collected natural enemies were parasitoids A. saccharicola and M. aclerdae, obtained in 10 and 8 sample points, respectively, three of common occurrence. Among the predators were drosofilids of the genus Rhinoleucophenga and the cocinellid Hyperaspis sp. in three and two sample points, respectively. The parasitoids emerged from scale insects collected in 16 sample points, while predators were obtained in only six. The sampling point where the number of parasitoid species, four being one associated with $S$. sacchari and $A$. takahashii was located in a sugar mill in the municipality of Fernandópolis, in a sugarcane field made up of plants at harvest point. The point where the highest number of predators was obtained, two dipterans and two parasitoids, refers to an area with a small cane plantation, semi-shaded, located in a small farm in the municipality of São Carlos, SP.

Although the two scale insects species studied can occur together, infesting the same plant structure, under the nodes of sheaths, the species of natural enemies obtained associated with each of them was distinct: seven for $A$. takahashii and five for $S$. sacchari. Among the natural enemies listed for these scale insects in the world, a single species common to both was recorded, the parasitic wasp Astymachus japonicus Howard, 1898, in China and India (Appendix A).

From the 15 species of natural enemies reported in association with S. sacchari and A. takahashii in Brazil, 10 species were found in this survey, in the state of São Paulo (Appendix A and B). The three species previously mentioned were associated with A. takahashii: R. obesa by Lima (1935) in the state of Rio de Janeiro; and, $R$. obesa, C. nigrescens and M. aclerdae by De Santis (1972) in the state of Alagoas.

The most frequent parasitoids were A. saccharicola and M. aclerdae. Anagyrus saccharicola is probably from Indo-Malayan region Timberlake (1932) has been introduced as a biological control agent of $S$. sacchari in several producers countries of sugarcane, as Hawaii, Australia and Egypt (Swezey, 1934; Carver, Inkerman, \& Ashbolt, 1987; Abd-Rabou, 2002). In Neotropical region this parasitoid was first successfully introduced and established in Barbados from the East African in 1970, reducing the pest population by over 90\% (Alam, 1972). Posteriorly it was also introduced in other Caribbean and South America countries. In South America this species was registered in Bolivia, Colombia, Guiana, Peru and Venezuela (Salazar, 1972; De Santis, 1979; Pruett \& Colque, 1984; Noyes \& Hayat, 1994; De Santis \& Fidalgo, 1994). In Brazil, this insect was probably accidentally introduced together with the pseudococcid. Mucrencyrtus aclerdae, probably original of Neotropical region, has a restricted distribution. Collected in association with $A$. takahashii, on sugarcane, in Alagoas and in Espírito Santo (De Santis, 1972; Culik \& Ventura, 2011), it has a distribution expanded to the Southeast Region.

The largest number of parasitoid species, observed from a single sampling point, emerged from A. takahashii, collected on plants of a sugarcane plant in the region of Fernandópolis. In this area, the population of Aclerdidae was predominant in relation to the mealybug and higher than in other areas, which probably favored the obtaining of the largest number of parasitoid species.

The largest number of predators, two dipterans, one associated with S. sacchari and one, A. takahashii, was observed in a small plantation of sugarcane, in a farm in São Carlos. Although the leaf sheath provides a protected environment for both the scale insect and its natural enemies, the fly larvae were probably even more favored because of the semi-shaded environment, which reduces the chances of desiccation.

The knowledge about predators and parasitoids of sugarcane scale insects population has a great importance, since for this crop biological control has already been used as a strategy to reduce some of the main pests such as Diatraea saccharalis (Fabricius, 1794) (Lepidoptera: Crambidae) with the parasite Cotesia flavipes Cameron, 1891 (Hymenoptera: Braconidae) and Mahanarva spp. with the entomopathogenic fungus Metarhizium anisopliae (Metschnikoff) (Parra, 2015).

\section{Conclusion}

The complex of natural enemies obtained during this work, composed of native and exotic species, including the occurrence of $A$. saccharicola used in biological control programs in other countries, will serve as a basis for future management programs in Brazil.

\section{References}

Abd-Rabou, S. (2000). Parasitoids attacking Saccharicoccus sacchari (Cockerell) (Hemiptera: Pseudococcidae) on sugarcane in Egypt. Sugarcane pest management in the New Millennium (pp. 72-75). 4th Sugarcane Entomology Workshop International Society of Sugar Cane Technologists, Khon Kaen, Thailand, February 7-10, 2000. International Society of Sugar Cane Technologists, c/o Bureau of Sugar Experiment Stations. 
Abd-Rabou, S. (2007). Biological control of Saccharicoccus sacchari (Coccoidea: Pseudococcidae) on sugar cane in Egypt using imported and indigenous natural enemies. Proceedings of the XI International Symposium on Scale Insect Studies, Oeiras, Portugal (pp. 24-27).

Alam, M. M. (1972). The establishment of Anagyrus saccharicola Timb. [Hymenoptera: Encyrtidae] in Barbados, West Indies, against the sugarcane mealybug, Saccharicoccus sacchari (Ckll.) (Hemiptera: Coccidae. Entomophaga, 17(4), 357-363. https://doi.org/10.1007/BF02371644

Almeida, L. M., \& Vitorino, M. D. (1997). A new species of Hyperaspis Redtenbacher (Coleoptera: Coccinellidae) and notes about the life habits. The Coleopterists'Bulletin, 213-216.

Andreotti, R., Wilson, W., Koller, W. W., Tadei, W. J., Prado, A., Barros, J. C., ... Gomes, A. (2003). Occurrence of the Megaselia scalaris (Loew, 1866) (Diptera, Phoridae) as a parasitoid of Boophilus microplus In Campo Grande, MS, Brazil. Revista Brasileira de Parasitologia Veterinária, 12(1), 46-47.

Anis, S. B., \& Hayat, M. (2002). A revision of the Indian species of Cheiloneurus Westwood (Hymenoptera: Chalcidoidea: Encyrtidae). Oriental Insects, 36(1), 129-209. https://doi.org/10.1080/00305316.2002. 10417330

Ashburner, M. (1981). Entomophagous and other bizarre Drosophilidae. In M. Ashburner, H. L. Carson, \& J. N. Thompson (Eds.), The Genetics and Biology of Drosophila (pp. 395-429). Academic Press, New York.

Autrey, L. J. C., Boolell, S., Lockhart, B. E. L., Jones, P., \& Nadif, A. (1995). The distribution of sugarcane bacilliform virus in various geographical regions. Proc Int Soc Sugar Cane Technol (Vol. 21, pp. 527-541).

Avellaneda, M. C., Diaz-Granados, C., An Gel, J. C., \& Victoria, J. (2001). Transmisión del virus baciliforme de la caña de azúcar (Sugarcane Bacilliform badnavirus ScBV) empleando Saccharicoccus sacchari como vector (p. 48). Cenicaña XXII Congreso de la Asociación Colombiana de Fitopatología y Ciencias afines, Medellín. Cali, Colombia.

Baltazar, C. R. (1966). A catalogue of Philippine Hymenoptera. Pacific Insects Monograph, 8, 1-488.

Barreto, B. T. (1932). Les chinches harinosas de la cana de azucar. Memorial de la Asociación Técnica Azucarera, 5, 132-134.

Beardsley Jr, J. W. (1962). Notes on the Biology of the Pink Sugar Cane Mealybug, Saccharicoccus sacchari (Cockerell), in Hawaii Homoptera: Pseudococcidae. Proceedings of the International Society of Sugarcane Technologists, 1, 954-961.

Bhuiya, B. A., Chowdhury, S. H., \& Kabir, M. H. (1997). An annotated list of chalcidoid parasitoids (Hymenoptera) of coccoidea (Hemoptera) on guava in Bangladesh. Bangladesh Journal of Zoology, 25, 53-64.

Box, H. E. (1950). The more important insect pests of sugar cane in northern Venezuela. Proceedings, Hawaiian Entomological Society, 14, 41-49.

Bugbee, R. E. (1967). Revision of the chalcid wasps of the genus Eurytoma in America north of Mexico. Proceedings of the United States National Museum, 118, 433-552. https://doi.org/10.5479/si.00963801. 118-3533.433

Campos, L. H. F., Carvalho, S. J. P., Christoffoleti, P. J., Fortes, C., \& Silva, J. S. (2010). Sistemas de manejo da palhada influenciam acúmulo de biomassa e produtividade da cana-de-açúcar (var. RB855453). Acta Scientiarum, 32(2), 1-9.

Carver, M., Inkerman, P. A., \& Ashbolt, N. J. (1987). Anagyrus saccharicola Timberlake (Hymenoptera: Encyrtidae) and other biota associated with Saccharicoccus sacchari (Cockerell) (Homoptera: Pseudococcidae) in Australia. Australian Journal of Entomology, 26(4), 367-368. https://doi.org/10.1111/ j.1440-6055.1987.tb01987.x

Chelvi, C. T., \& Kandasamy, R. (2009). Field efficacy of Chrysopa scelestis Bank against sugarcane mealybug Saccaricoccus sacchari Cockerell. Cooperative Sugar, 41, 37-39.

CIBC. (1976). Report of work carried out during 1975. Commonwealth Institute of Biological Control, Commonwealth Agricultural Bureaux (p. 65). Slough, U.K.

Compere, H., \& Annecke, D. P. (1961). Descriptions of parasitic Hymenoptera and comments (Hymenopt.: Aphelinidae, Encyrtidae, Eulophidae). Journal of the Entomological Society of southern Africa, 24, 17-71. 
Compere, H. (1936). New genus and species of Encyrtidae parasitic in the pineapple mealybug, Pseudococcus brevipes (Ckll.). Proceedings of the Hawaiian Entomological Society, 9, 173-200.

Costa, A. L. (1935). Um drosophilídeo predador de coccídeos. Chácaras e Quintais, 52, 61-63.

Costa, J., Almeida, C. E., Esperança, G. M., Morales, N., Mallet, J. R. D. S., Gonçalves, T., \& Prado, A. P. D. (2007). First record of Megaselia scalaris (Loew) (Diptera: Phoridae) infesting laboratory colonies of Triatoma brasiliensis Neiva (Hemiptera: Reduviidae). Neotropical Entomology, 36(6), 987-989. https://doi.org/10.1590/S1519-566X2007000600026

Culik, M. P., \& Ventura, J. A. (2009). New species of Rhinoleucophenga, a potential predator of pineapple mealybugs. Pesquisa Agropecuária Brasileira, 44(4), 417-420. https://doi.org/10.1590/S0100-204X2009 000400013

Culik, M. P., Martins, D. D. S., \& Ventura, J. A. (2011). New distribution and host records of chalcidoid parasitoids (Hymenoptera: Chalcidoidea) of scale insects (Hemiptera: Coccoidea) in Espírito Santo, Brazil. Biocontrol Science and Technology, 21(7), 877-881. https://doi.org/10.1080/09583157.2011.588319

Culik, M., \& Ventura, J. (2013). A new species of cecidomyiid (Diptera: Cecidomyiidae) predator of scale insect (Hemiptera: Coccoidea) pests of pineapple. Acta Phytopathologica et Entomologica Hungarica, 48(1), 129-134. https://doi.org/10.1556/APhyt.48.2013.1.11

Culik, M. P., \& Ventura, J. A. (2013). Two New Neotropical Species of Midge (Diptera: Cecidomyiidae) Predators of Scale Insects (Hemiptera: Coccoidea). Journal of the Entomological Research Society, 15(2), 103-111.

De Barro, P. J. (1990). Natural enemies and other species associated with Saccharicoccus sacchari (Cockerell) (Hemiptera: Pseudococcidae) in the Bundaberg area, southeast Queensland. Australian Journal of Entomology, 29(2), 87-88. https://doi.org/10.1111/j.1440-6055.1990.tb00322.x

De Santis, L. (1964). Encirtidos de la República Argentina (Hymenoptera: Chalcidoidea). Comisión de Investigación Cientifica Provincia de Buenos Aires, 4, 9-422.

De Santis, L. (1972). Complejo entomofagico de Aclerda campinensis (Hom.) en el estado de Alagoas (Brasil). Anais da Sociedade Entomológica do Brasil, 1, 17-24.

De Santis, L. (1979). Catálogo de los himenópteros calcidoideos de América al sur de los Estados Unidos (p. 488). La Plata, Argentina.

De Santis, L. (1983). Catálogo de los Himenopteros Calcidoideos de America al Sur de los Estados Unidos-Primer Suplemento. Revista Peruana de Entomología, 24, 1-11.

Digiulio, J. A. (1997). Eurytomidae. In G. A. P. Gibson, J. T., Huber, \& J. B. Woolley (Eds.), Annotated keys to the genera of Nearctic Chalcidoidea (Hymenoptera) (pp. 477-495). Ottawa: NRC Research Press.

Disney, R. H. (2008). Natural history of the scuttle fly, Megaselia scalaris. Annual Review of Entomology, 53, 30-60. https://doi.org/10.1146/annurev.ento.53.103106.093415

Drummond, J., De Barro, P. J., \& Pinnock, D. E. (1991). Field and laboratory studies on the fungus Aspergillus parasiticus, a pathogen of the pink sugar cane mealybug Saccharicoccus sacchari. Biological Control, 1(4), 288-292. https://doi.org/10.1016/1049-9644(91)90080-J

Félix, A. R., Vasconcelos, J., Brazão, C. I., Aguiar, A. M. F., \& Rocha, M. (2004). Aspectos bioecológicos de Hyperaspis pantherina Fursch (Coleoptera: Coccinellidae) predador de Orthezia insignis Browne (Homoptera: Ortheziidae). Boletín de Sanidad Vegetal Plagas, 30, 347-354.

Fluker, S. S., Huddleston, E. W., \& Beardsley, J. W. (1968). Some effects of the big-headed ant on populations of the pink sugarcane mealybug. Journal of Economic Entomology, 61(2), 474-477. https://doi.org/10.10 93/jee/61.2.474

Fry, J. M. (1989). A catalogue of natural enemies of arthropods derived from records in the CIBC Natural Enemy Databank (p. 73). CAB International, Wallingford, Oxford.

Gagné, R. J. (1994). The gall midges of the Neotropical region (p. 352). Cornell University Press, USA.

Gagné, R. J. (2010). Update for a catalog of the Cecidomyiidae (Diptera) of the world (p. 545). USDA, Washington. 
Gahan, A. B. (1946). Eight new species of chalcid-flies of the genus Pseudaphycus Clausen, with a key to the species. Proceedings of the United States National Museum, 96, 311-327. https://doi.org/10.5479/si.0096 3801.96-3200.311

Gamal El-Dein, H., Mohamed Sanaa, A., Ibrahim, M., \& Fatma, A. M. (2009). Effect of Saccharicoccus sacchari (Cockerell) infestation levels on sugarcane physical and chemical properties. Egypt. Acad. J. Biolog. Sci., 2(2), 119-123.

García Morales, M., Denno, B. D., Miller, D. R., Miller, G. L., Ben-Dov, Y., \& Hardy, N. B. (2016). ScaleNet: A literature-based model of scale insect biology and systematics.

Girón, K., Lastra, L. A., Gómez, L. A., \& Mesa, N. C. (2005). Observaciones acerca de la biología y los enemigos naturales de Saccharicoccus sacchari y Pulvinaria poselongata, dos homópteros asociados con la hormiga loca en caña de azúcar. Revista Colombiana de Entomología, 31(1), 29-35.

González, F. G., \& Gordon, R. D. (2009). New species of Hyperaspis Chevrolat from Chile and Argentina (Coleoptera: Coccinellidae). Boletín Sociedad Entomológica Aragonesa, 44, 77-82.

Gordon, R. D. (1985). The Coccinellidae (Coleoptera) of America north of Mexico. Journal of New York Entomology Society, 93, 1-912.

Gordon, R. D. (2008). South America Coccinellidae (Coleoptera) Part XI: A Systematic Revision of Hyperaspidini (Hyperaspidinae). Annali del Museo Civico di Storia Naturale “G. Doria”, 119, $245-512$.

Granara de Willink, M. C. (1996). El género Cerococcus en la Argentina (Homoptera: Cerococcidae). Insecta Mundi, 10, 235-238.

Grimaldi, D. A. (1990). A phylogenetic, revised classification of genera in the Drosophilidae (Diptera). Bulletin of the American Museum of Natural History, 197, 103-268.

Gullan, P. J., \& Kosztarab, M. (1997). Adaptations in scale insects. Annual Review of Entomology, 42(1), 23-50. https://doi.org/10.1146/annurev.ento.42.1.23

Hadden, F. C., \& Lopez, A. W. (1931). Efforts towards biological control of the common pink mealy bug Trionymus sacchari (Cockerell) of Sugarcane on Negros. Philippine Journal of Science, 46, 221-223.

Hafez, M., \& Salama, H. S. (1967, March). Polymorphism in the male of the mealy bug Saccharicoccus sacchari (Cockerell). Proceedings of the Royal Entomological Society of London. Series A, General Entomology (Vol. 42, No. 1-3, pp. 25-29). Oxford, UK: Blackwell Publishing Ltd.

Hafez, M., \& Salama, H. S. (1969). Biological studies on the sugar cane mealy bug, Saccharicoccus sacchari Ckll., in Egypt (Hemiptera-Homoptera: Coccoidea). Bulletin de la Societe Entomologique d'Egypte, 53, 499-516.

Hambleton, E. J. (1935). Notas sobre Pseudococcinae de importância econômica no Brasil com a descrição de quatro espécies novas. Arquivos do Instituto Biológico, 13, 105-200.

Harris, K. M. (1968). A systematic revision and biological review of the cecidomyiid predators (Diptera: Cecidomyiidae) on world Coccoidea (Hemiptera-Homoptera). Transactions of the Entomological Society of London, 119, 401-494. https://doi.org/10.1111/j.1365-2311.1968.tb00504.x

Hayat, M. (1979). Indian species of Anagyrus (Hym.: Encyrtidae) (p. 177). Oriental Insects, India.

Hayat, M. (1981). Taxonomic notes on Indian Encyrtidae (Hymenoptera: Chalcidoidea) (pp. 13-34). Colemania.

Hayat, M. (2006). Indian Encyrtidae (Hymenoptera: Chalcidoidea) (p. 274). Department of Zoology, Aligarh Muslim University, India.

Hayat, M., \& Subba Rao, B. R. (1986). Family Encyrtidae. In B. R. Subba Rao, \& M. Hayat (Eds.), The Chalcidoidea (Insecta: Hymenoptera) of India and the adjacent countries. Part II. Oriental Insects (pp. 20-75). India. https://doi.org/10.1080/00305316.1986.10433723

Hernandez, M., Ceballos, M., \& Noyes, J. S. (1993). Anagyrus saccharicola Timberlake (Hymenoptera: Encyrtidae), new report for Cuba as a parasitoid of Saccharicoccus sacchari (Ckll) on sugarcane. Revista de Protección Vegetal, 8, 311-313.

Herting, B. (1972). Homoptera Catalogue of Parasites and Predators of Terrestrial Arthropods. Host or Prey/Enemy (p. 1127). Commonwealth Agricultural Bureaux, Slough, England. 
Hochmüller, C. J., Silva, M. L., Valente, V. L. S., \& Schmitz, H. J. (2010). The drosophilid fauna (Diptera, Drosophilidae) of the transition between the Pampa and Atlantic Forest Biomes in the state of Rio Grande do Sul, southern Brazil: first records. Papeis Avulsos de Zoologia, 50, 285-295.

Howard, L. O. (1897). On the Chalcididae of the Island of Grenada. Journal of the Linnean Society of London, Zoology, 26(166), 129-178. https://doi.org/10.1111/j.1096-3642.1897.tb00244.x

Husain, T., \& Khan, M. Y. (1986). Family Eulophidae. The Chalcidoidea (Insecta: Hymenoptera) of India and the adjacent countries. Insects, 20, 237-241.

IIBC (International Institute of Biological Control). (1992). Annual Report CAB International (p. 55). Wallingford, UK.

Japoshvili, G., \& Celik, H. (2010). Fauna of Encyrtidae, parasitoids of coccids in Golcuk Natural Park. Entomologia Hellenica, 19(2), 132-136. https://doi.org/10.12681/eh.11580

Kapadia, M. N., \& Mittal, V. P. (1994). Biology of Anagyrus punctulatus Agarwal, a parasitoid of Saccharicoccus sacchari (Cockerell) and a residual toxicity of certain insecticides to adult parasitoids. Gujarat Agricultural University Research Journal, 19, 44-49.

Kapadia, M. N., Parsana, G. J., \& Butani, P. G. (1995). Field recovery of Anagyrus punctulatus Agarwal, a parasitoid of the sugarcane mealybug. Indian Sugar, 45(6), 361-362.

Koller, W. W., Andreotti, R., Zanon, A. M., Gomes, A., \& Barros, J. C. (2003). Mosca Megaselia scalaris (Loew) (Diptera: Phoridae), parasita do carrapato bovino Boophilus microplus (Canestrini): Uma revisão (p. 34). Embrapa Gado de Corte, Campo Grande.

Lim, G. T., \& Pan, Y. C. (1976). Parasites of the sugarcane scale insect Aclerda takahashii (Kuw.). Entomology Newsletter (South Africa), 3, 1-4.

Lim, G. T., \& Pan, Y. C. (1980). Entomofauna of sugarcane in Malaysia, Entomology, 8, 1658-1679.

Lima, A. C. (1935). Um drosophilideo predador de coccídeos. Chácaras e Quintais, 52, 61-63.

Lima, A. C. (1937). Outras moscas cujas larvas são predadoras de coccídeos. Chácaras e Quintais, 55, 179-182.

Lima, A C. (1950). Duas espécies de Gitona predadoras de coccídeos do gênero Orthezia (Diptera: Drosophilidae). Arthropoda, 1, 247-253.

Liu, G., Zhou, T., Dai, P., \& Zhang, X. (2014). A new species of Megaselia rondani 1856 (Diptera: Phoridae) associated with Apis laboriosa Smith 1871 (Hymenoptera: Apidae) in China. Pacific Coast Entomological Society, 90(1), 33-36.

López, P. M. (2003). A preliminary list of the Encyrtidae (Hymenoptera: Chalcidoidea) of Cuba, with descriptions of two new species. Journal of Hymenoptera Research, 12, 1-26.

Lockhart, B. E. L., Autrey, L. J. C., \& Comstock, J. C. (1992). Partial purification and serology of sugarcane mild mosaic vírus, a mealybug-transmitted clorestolike vírus. Phytopathology, 82, 691-695. https://doi.org/ 10.1094/Phyto-82-691

Majka, C. G., \& Robinson, S. (2009). Hyperaspis and Brachiacantha (Coleoptera: Coccinellidae): two poorly known genera of native lady beetles in the Maritime Provinces. Journal of the Acadian Entomological Society, 5(2), 3-11.

Malogolowkin, C. (1946). Sobre o gênero Rhinoleucophenga com descrição de cinco espécies novas (Drosophilidae, Diptera). Revista Brasileira de Biologia, 6, 415-426.

Mcconnell, H. S. (1954). A classification of the coccid family Aclerdidae (Coccoidea, Homoptera). Bulletin of the Maryland Agriculture Experiment Station, 75, 11-21.

Napompeth, B. (1978). Sugarcane insect pest management (pp. 66-67). Proceedings of 31st New Zealand Weed and Pest Control Conference, New Zealand.

Nieves, J. J. (1999). Manejo, Prevención y Control de la Hormiga Loca Paratrechina fulva (Mayr), en caña para panela. ICA, 1, 4-21.

Noyes, J. S. (1980). A review of the genera of Neotropical Encyrtidae (Hymenoptera: Chalcidoidea). Bulletin of the British Museum (Natural History) (Entomology), 41, 107-253. 
Noyes, J. S. (2000). Encyrtidae of Costa Rica (Hymenoptera: Chalcidoidea), 1. The subfamily Tetracneminae, parasitoids of mealybugs (Homoptera: Pseudococcidae). Memoirs of the American Entomological Institute, $62,1-355$.

Noyes, J. S. (2010). Encyrtidae of Costa Rica (Hymenoptera: Chalcidoidea), 3. Subfamily Encyrtinae: Encyrtini, Echthroplexiellini, Discodini, Oobiini and Ixodiphagini, parasitoids associated with bugs (Hemiptera), insect eggs (Hemiptera, Lepidoptera, Coleoptera, Neuroptera) and ticks (Acari). Memoirs of the American Entomological Institute, 12, 1-848.

Noyes, J. S. (2017). Universal Chalcidoidea Database. Retrieved from http://www.nhm.ac.uk/chalcidoids

Noyes, J. S., \& Hayat, M. (1994). Oriental mealybug parasitoids of the Anagyrini (Hymenoptera: Encyrtidae). (p. 554). CAB International, Oxon.

Parra, J. R. P. (2015). Controle biológico no Brasil: O exemplo da cana-de-açúcar. STAB-Seminário sobre pragas e doenças na cana-de-açúcar-Wilson Roberto Trevisan Novaretti, Piracicaba, SP. Retrieved October 4, 2018, from http:/www.stab.org.br/palestras_web_pragas_2015/parra_2015.pdf

Parsana, G. J., Butani, P. G., \& Kapadia, M. N. (1996). Parasitism of the sugarcane mealybug, Saccharicoccus sacchari (Cockerell) in relation to the weather parameters. Gujarat Agricultural University Research Journal, 21, 141-143.

Patterson, J. T. (1943). The Drosophilidae of the Southwest. The University of Texas Publication, 4313, 7-216.

Poppe, J. L., Valente, V. L. S., Santos, J. P. J., \& Gottschalk, M. S. (2016). A new species of the genus Rhinoleucophenga (Diptera: Drosophilidae) and redescription of five species from Neotropical region. Zootaxa, 4208, 261-281. https://doi.org/10.11646/zootaxa.4208.3.5

Prado, E., Alvarenga, T. M., \& Santa-Cecília, L. V. C. (2015). Parasitoids associated with the black scale Saissetia oleae (Olivier) (Hemiptera: Coccidae) in olive trees in Minas Gerais State, Brazil. Acta Scientiarum. Agronomy, 37(4), 411-416. https://doi.org/10.4025/actasciagron.v37i4.19743

Prinsloo, G. L. (1983). A parasitoid-host index of Afrotropical Encyrtidae (Hymenoptera: Chalcidoidea). Entomology Memoirs of the Department of Agriculture, Republic of South Africa, 60, 4-30.

Prinsloo, G. L., \& Annecke, D. P. (1978). On some new and described Encyrtidae (Hymenoptera: Chalcidoidea) from the Ethiopian region. Journal of the Entomological Society of Southern Africa, 41, 270-313.

Pruett, C. J. H., \& Colque, A. E. (1984). The occurrence and distribution of Saccharicoccus sacchari and its parasite Anagyrus saccharicola in sugarcane in the Bolivian orient. Entomology Newsletter, 16, 11-13.

Puttarudriah, M. (1954). The status of the mealybug on sugarcane with special reference to Mysore State. Indian Journal of Entomology, 16, 1-10.

Rajendra, A. (1974). The biology and control of Saccharicoccus sacchari Ckll. (Hom: Pseudococcidae) the pink mealy bug of sugarcane in Sri Lanka. Ceylon Journal of Science, Biological Sciences, 11, 23-28.

Reddy, D. J., \& Aziz, S. A. (2000). Record of Dicrodiplosis sp. on sugarcane mealybug. Insect Environment, 6(3), 100-104.

Rezende, J. A. M., Rossetto, C. J., \& Germeck, E. B. (1979). Incidência de Saccharicoccus sacchari (Cockerell, 1895) (Homoptera, Coccoidea, Pseudococcidae) em variedades de cana-de-açúcar. Bragantia, $38,1-4$. https://doi.org/10.1590/S0006-87051979000100032

Schmiedeknecht, O. (1909). Hymenoptera fam. Chalcididae. Genera Insectorum, 1, 1-550.

Shafee, A. S., Alam, M., \& Agarwal, M. M. (1975). Taxonomic survey of encyrtid parasites (Hymenoptera: Encyrtidae) in India. Aligarh Muslim University Publication, Zoological Series on Indian Insect Types, 10, 33-34.

Sharkov, A. (1996). A review of the species of Mucrencyrtus Noyes (Hymenoptera: Encyrtidae). Proceedings of the Entomological Society of Washington, 98, 350-368.

Sharkov, A., \& Woolley, J. B. (1997). A revision of the genus Hambletonia Compere (Hymenoptera: Encyrtidae). Journal of Hymenoptera Research, 6, 191-218.

Singh, A., Solanki, R. S., \& Malik, K. (1997). First record of Batrachedra sp. near psilopa Meyrick (Lepidoptera: Momphidae) as a parasite of sugarcane mealybug. Insect Environment, 3, 36-37. 
Souza, Z. M. D., Paixão, A. C. S., Prado, R. D. M., Cesarin, L. G., Souza, S. R. D., \& Montanari, R. (2008). Produtividade agrícola de variedades de cana-de-açúcar e incidência de broca-comum e cigarrinha-da-raiz em canavial colhido sem queima. Bragantia, 67, 413-419. https://doi.org/10.1590/S0006-8705200800 0200017

Stocks, I. (2016). The flat grass scale, Aclerda takahashii Kuwana (Hemiptera: Aclerdidae), a new pest of sugarcane in Florida. Florida Department of Agriculture and Consumer Services Division of Plant Industry, $1,1-3$.

Subba Rao, B. R. (1980). Botryoideclava bharatiya, Gen. Et S. Nov, and a new species of Eriaphytis Hayat from India (Hymenoptera: Aphelinidae). Oriental Insects, 14, 41-45. https://doi.org/10.1080/00305316.1980.104 34581

Sullivan, D. J., Castillo, J. A., \& Bellotti, A. C. (1991). Comparative biology of six species of coccinellid beetles (Coleoptera: Coccinellidae) predaceous on the mealybug, Phenacoccus herreni (Homoptera: Pseudococcidae), a pest of cassava in Colombia, South America. Environmental Entomology, 20(2), 685-689. https://doi.org/10.1093/ee/20.2.685

Swezey, O. H. (1934). Biological Control of insect pests in Hawaii. Proceedings of the 5th Pacific Science Congress, 5, 35-32.

Tachikawa, T. (1963). A new and economically important species of sugarcane scale from the Ryukyus (Hym. Chalc. Encyrtidae) (p. 131). Mushi.

Thompson, W. R. (1955). A catalogue of the parasites and predators of insect pests. Section 2-Host parasite catalogue (p. 232). Commonwealth Agricultural Bureaux, The Commonwealth Institute of Biological Control, Ontario, Canada.

Throckmorton, L. H. (1962). The Problem of Phylogeny in the Genus Drosophila. Studies in Genetics, 2, 207-343.

Timberlake, P. H. (1932). Three New Parasitic Hymenoptera from the Indo-Malayan Region. Proceedings of the Hawaiian Entomological Society, 8, 153-162.

Tohamy, T. H., El-Raheem, A. A., \& El-Rawy, A. M. (2008). Role of the cultural practices and natural enemies for suppressing infestation of the pink sugarcane mealybug, Saccharicoccus sacchari (Cockerell) (Hemiptera: Pseudococcidae) in sugarcane fields at Minia Governorate, Middle Egypt. Egyptian Journal of Biological Pest Control, 18(1), 177-188.

Trjapitzin, V. A. (1989). Parasitic Hymenoptera of the Fam. Encyrtidae of Palaearctics (pp. 1-135). Zoologicheskim Institutom Akademii Nauk SSR, Leningrad.

Trjaptizin, V. A., \& Zuparko, R. L. (2004). A synopsis of the genus Cheiloneurus Westwod, 1833 (Hymenoptera: Chalcidoidea: Encyrtidae) of the New World. Russian Entomological Journal, 13, 257-266.

Tsacas, L., \& Chassagnard, M. T. (1999). The Afrotropical species of the subgenus Gitonides Knab of the genus Cacoxenus Loew, with larvae predatory on mealybugs (Diptera: Drosophilidae). Annales de la Société Entomologique de France, 35, 91-121.

Tumrasvin, W., Sucharit, S., \& Vutikes, S. (1997). Studies on the life history of Megaselia scalaris (Loew) in Thailand. The Southeast Asian Journal of Tropical Medicine and Public Health, 8, 74-76.

Uichanco, L. B., \& Villanueva, F. E. (1932). Biology of the pink mealybug of sugarcane, Trionymus sacchari (Cockerell), in the Philippines. Philippine Agriculturist, 21, 237-241.

Vandenberg, N. J. (2002). Coccinellidae Latreille 1807. In R. H. Arnett, M. C. Thomas, P. E. Skelley, \& J. H. Frank (Eds.), American Beetles (pp. 371-389). CRC Press.

Vidal, M. C., \& Vilela, C. R. (2015). A New Species of Rhinoleucophenga (Diptera: Drosophilidae) From the Brazilian Cerrado Biome Associated with Extrafloral Nectaries of Qualea grandiflora (Vochysiaceae). Annals of Entomological Society of America, 108(5), 932-940. https://doi.org/10.1093/aesa/sav077

Victoria, J. I., Avellaneda, M. C., Angel, J. C., \& Guzmán, M. L. (2005). Resistance to Sugarcane yellow leaf virus in Colombia. Proc. Intern. Soc. Sugar Cane Technologists, 25, 664-670.

Williams, D. J., \& Granara de Willink, M. C. (1992). Mealybugs of Central and South America (p. 635). CAB International, London, England. 
Wyckhuys, K. A. G., Kondo, T., Herrera, B. V., Miller, D. R., Naranjo, N., \& Hyman, G. (2013). Invasion of Exotic Arthropods in South America's Biodiversity Hotspots and Agro-Production Systems. In J. Peña (Eds.), Potential Invasive Pests of Agricultural Crops (pp. 373-400). CABI Invasives Series, University of Florida, USA. https://doi.org/10.1079/9781845938291.0373

Xi, Y. Q., Zhang, Y. Z., Zhu, C. D., \& Yin, X. M. (2010). Astymachus and Boucekiella (Hymenoptera: Encyrtidae) from China. Oriental Insects, 44(1), 11-16. https://doi.org/10.1080/00305316.2010.10417601

Zhang, Y. Z., \& Xu, Z. H. (2009). A review of Chinese species of Leptomastidea Mercet (Hymenoptera: Encyrtidae). Acta Entomologica Sinica, 52(4), 420-423.

\section{Appendix A}

Revision of natural enemies associated with Aclerda takahashii (Kuwana, 1932) and Saccharicoccus sacchari (Cockerell, 1895) in the world

\begin{tabular}{|c|c|c|c|}
\hline \multirow{2}{*}{ NATURAL ENEMIES } & \multicolumn{2}{|c|}{ Scale insects } & \multirow{2}{*}{ References } \\
\hline & $A$ & $S$ & \\
\hline \multicolumn{4}{|l|}{ COLEOPTERA } \\
\hline \multicolumn{4}{|l|}{ Coccinelidae } \\
\hline Coccinella undecimpunctata (L., 1758) & & $x$ & EGY (Abd-Rabou, 2007; Tohamy et al., 2008) \\
\hline Cryptolaemus montrouzieri Mulsant, 1853 & & $x$ & BAR AUS, (Alam, 1972; Carver et al., 1987) \\
\hline Halmus ovalis (Blackburn, 1892) & & $x$ & AUS (De Barro, 1990) \\
\hline Hyperaspis spp. & & $\times$ & BRA, BAR (Alam, 1972) \\
\hline Hyperaspis notata Crotch, 1874 & & $x$ & COL (Pruett \& Colque, 1984) \\
\hline Hyperaspis trilineata Mulsant, 1850 & & $x$ & $\begin{array}{l}\text { BAR, COL, EGY, VEN (Box, 1950; Alam, 1972; Pruett \& Colque, } \\
\text { 1984; Abd-Rabou, 2007) }\end{array}$ \\
\hline Nephus sp. & & $x$ & BAR (Alam, 1972) \\
\hline Rodolia cardinalis (Mulsant, 1850) & & $x$ & EGY (Tohamy et al., 2008) \\
\hline Scymnus syriaca Mars, 1958 & & $x$ & EGY (Abd-Rabou, 2007) \\
\hline Scymnus syriacus (Marseul, 1898) & & $x$ & EGY (Tohamy et al., 2008) \\
\hline Scymnus sp. & & $x$ & PHI (Hadden \& Lopez 1931) \\
\hline \multicolumn{4}{|l|}{ Staphylinidae } \\
\hline Oligota barbadorum (Frank, 1972) & & $x$ & BAR (Alam, 1972) \\
\hline Paederus alfierii Koch, 1974 & & $x$ & EGY (Abd-Rabou, 2007; Tohamy et al., 2008) \\
\hline \multicolumn{4}{|l|}{ Nitidulidae } \\
\hline Carpophilus mutilatus Erichson, 1843 & & $x$ & SRI (Rajendra, 1974) \\
\hline \multicolumn{4}{|l|}{ Cucujidae } \\
\hline Oryzaephilus sp. & & $x$ & SRI (Rajendra, 1974) \\
\hline \multicolumn{4}{|l|}{ LEPIDOPTERA } \\
\hline \multicolumn{4}{|l|}{ Pyralidae } \\
\hline Isauria aphidovora (Meyrick, 1850) & & $x$ & AUS (De Barro, 1990) \\
\hline \multicolumn{4}{|l|}{ Momphidae } \\
\hline Batrachedra aff. psilopa & & $x$ & IND (Singh et al., 1997) \\
\hline \multicolumn{4}{|l|}{ DIPTERA } \\
\hline \multicolumn{4}{|l|}{ Drosophilidae } \\
\hline Cacoxenus polyodous Tsacas \& Chassangnard, 1999 & & & MAD (Tsacas \& Chassagnard, 1999) \\
\hline Cacoxenus perspicax (Knab, 1914) & & $x$ & $\begin{array}{l}\text { AUS, EUA, MAD (Ashburner, 1981; Carver et al., 1987; De Barro, } \\
\text { 1990; Drummond et al., 1991; Tsacas \& Chassagnard, 1999) }\end{array}$ \\
\hline Rhinoleucophenga obesa (Loew, 1872) & $\times$ & & BRA (Lima, 1935; De Santis, 1972) \\
\hline \multicolumn{4}{|l|}{ Cecidomyiidae } \\
\hline Coccodiplosis sp. & & $x$ & AUS (Carver et al., 1987) \\
\hline Diadoplosis sp. & & $x$ & COL (Giron et al., 2005) \\
\hline \multicolumn{4}{|l|}{ DIPTERA } \\
\hline \multicolumn{4}{|l|}{ Cecidomyiidae } \\
\hline Species not determined & & $\times$ & BAR (Alam, 1972) \\
\hline \multicolumn{4}{|l|}{ Phoridae } \\
\hline Megaselia spp. & & $x$ & BRA, SRI (Rajendra, 1974) \\
\hline \multicolumn{4}{|l|}{ DERMAPTERA } \\
\hline \multicolumn{4}{|l|}{ Forficulidae } \\
\hline Elaunon bipartitus (Kirby, 1891) & & $x$ & AUS (De Barro, 1990) \\
\hline
\end{tabular}




\begin{tabular}{|c|c|c|c|}
\hline \multicolumn{4}{|l|}{ Labiduridae } \\
\hline Nala lividipes (Dufour, 1828) & & $x$ & AUS (De Barro, 1990) \\
\hline \multicolumn{4}{|l|}{ HEMIPTERA } \\
\hline \multicolumn{4}{|l|}{ Anthocoridae } \\
\hline Oplobates woodwardi (Gross, 1957) & & $\times$ & AUS (Carver et al., 1987) \\
\hline Orius sp. & & $x$ & EGY (Abd-Rabou, 2007) \\
\hline \multicolumn{4}{|l|}{ HEMIPTERA } \\
\hline \multicolumn{4}{|l|}{ Anthocoridae } \\
\hline Orius albidipenis (Reuter,1884) & & $\times$ & EGY (Tohamy et al., 2008) \\
\hline \multicolumn{4}{|l|}{ Geocoridae } \\
\hline Geocoris sp. & & $\times$ & EGY (Tohamy et al., 2008) \\
\hline \multicolumn{4}{|l|}{ NEUROPTERA } \\
\hline \multicolumn{4}{|l|}{ Chrysopidae } \\
\hline Chrysoperla carnea (Stephens, 1836) & & $\times$ & EGY (Abd-Rabou, 2007) \\
\hline Chrysopa innota Walker, 1853 & & $\times$ & AUS (De Barro, 1990) \\
\hline Crysopa scelestis Banks, 1950 & & $\times$ & IND (Chelvi \& Kandasamy, 2009) \\
\hline \multicolumn{4}{|l|}{ HYMENOPTERA } \\
\hline \multicolumn{4}{|l|}{ Aphelinidae } \\
\hline Botryoideclava bharatiya Subba Rao,1980 & & $x$ & IND (Subba Rao, 1980) \\
\hline \multicolumn{4}{|l|}{ HYMENOPTERA } \\
\hline \multicolumn{4}{|l|}{ Encyrtidae } \\
\hline Acerophagus mundus Gahan, 1946 & & $x$ & CHN, CRC, GEO (Gahan, 1946; Trjapitzin, 2008; Noyes, 2010) \\
\hline Anagyrus saccharicola Timberlake, 1932 & & $\times$ & $\begin{array}{l}\text { AFG, AUS, BAR, BOL, COL, CRC, CUB, EGY, EUA, FIJ, GUY, } \\
\text { IND, JAM, JPN, MEX, MAS, NCA, PER, PHI, THA, VEN } \\
\text { (Timberlake, 1932; Swezey, 1934; Thompson, 1955; Baltazar, 1966; } \\
\text { Fluker et al., 1968; Alam, 1972; Herting, 1972; Napompeth, 1978; De } \\
\text { Santis, 1979; Hayat, 1979; Prinsloo, 1983; Pruett \& Colque, 1984; } \\
\text { Hayat, 1986; Carver et al., 1987; Fry, 1989; Trjapitzin, 1989; De Barro, } \\
\text { 1990; Drummond et al., 1991; Hernandez et al., 1993; Noyes \& Hayat, } \\
\text { 1994; López, 2003; Trjapitzin et al., 2004; Abd-Rabou, 2007; Tohamy } \\
\text { et al., 2008) }\end{array}$ \\
\hline \multicolumn{4}{|l|}{ HYMENOPTERA } \\
\hline \multicolumn{4}{|l|}{ Encyrtidae } \\
\hline Adelencyrtus chionaspidis Howard, 1896 & & $\times$ & CUB (De Santis, 1979) \\
\hline Adelencyrtus moderatus Howard, 1897 & & $\times$ & $\begin{array}{l}\text { GRN, IND (Schmiedeknecht, 1909; Compere \& Annecke 1961; } \\
\text { Tachikawa, 1963; Hayat, 1981; Howard, 1897) }\end{array}$ \\
\hline Aeptencyrtus bruchi De Santis, 1957 & & $\times$ & CUB (De Santis, 1983; Noyes \& Hayat 1994; López, 2003) \\
\hline Anagyrus aligarhensis Agarwal \& Alam, 1959 & & $\times$ & $\begin{array}{l}\text { IND, TUR (Hayat, 1979; Kapadia \& Mittal 1994; Noyes \& Hayat } \\
\text { 1994; Kapadia et al., 1995; Parsana et al., 1996; Japoshvili \& Celik } \\
\text { 2010) }\end{array}$ \\
\hline Anagyrus dactylopii Howard, 1898 & & $x$ & PHI (Baltazar, 1966; Trjapitzin, 1989; Noyes \& Hayat 1994) \\
\hline Anagyrus greeni Howard 1896 & & $\times$ & EGY, (Noyes \& Hayat 1994; Abd-Rabou, 2000; 2007) \\
\hline Anagyrus mirzai Agarwal \& Alam, 1959 & & $\times$ & - (Noyes \& Hayat 1994) \\
\hline Anagyrus pseudococci (Girault, 1915) & & $\times$ & EGY, (Noyes \& Hayat 1994; Abd-Rabou, 2000; 2007) \\
\hline Anagyrus pulchricornis Howard, 1894 & & $\times$ & - (De Santis, 1979; Noyes \& Hayat 1994) \\
\hline Anagyrus punctulatus Agarwal \& Alam, 1959 & & $\times$ & IND (Hayat, 1979; Kapadia et al., 1995) \\
\hline Anagyrus swezeyi Timberlake, 1919 & & $\times$ & EUA, IND (CIBC, 1976; Hayat, 1979; Hayat, 1986; IIBC, 1992) \\
\hline Anagyrus sp. & & $x$ & $\begin{array}{l}\text { BER, CUB, PHI (Hadden \& Lopez 1931; Uichanco \& Villanueva } \\
\text { 1932; Thompson, 1955; Baltazar, 1966; Herting 1972, Noyes \& Hayat } \\
\text { 1994, Trjapitzin et al., 2004) }\end{array}$ \\
\hline Astymachus japonicus Howard, 1898 & $\times$ & $\times$ & $\begin{array}{l}\text { CHN, IND (Hayat, 1986; Trjapitzin, 1989; Noyes \& Hayat 1994; Xi et } \\
\text { al., 2010) }\end{array}$ \\
\hline \multicolumn{4}{|l|}{ HYMENOPTERA } \\
\hline \multicolumn{4}{|l|}{ Encyrtidae } \\
\hline $\begin{array}{l}\text { Cheiloneurus nigrescens Howard, } 1897 \\
\text { (=Cheiloneurus longisetaceus De Santis, 1939) }\end{array}$ & $x$ & & BRA (De Santis, 1972; Trjapitzin \& Zuparko, 2004) \\
\hline Holcencyrtus osborni Timberlake, 1923 & & $\times$ & (Thompson, 1955; Noyes \& Hayat, 1994) \\
\hline Cladiscodes sacchari Subba Rao, 1977 & & $\times$ & IND (Subba Rao, 1977; Hayat, 1986; Noyes \& Hayat, 1994) \\
\hline Cheiloneurus hadrodorys Anis \& Hayat, 2002 & & $\times$ & NEP (Anis \& Hayat 2002) \\
\hline Species not determined & & $\times$ & COL (Giron et al., 2005) \\
\hline Mayrencyrtus sp. & & $\times$ & - (Noyes \& Hayat, 1994) \\
\hline
\end{tabular}




\begin{tabular}{|c|c|c|c|}
\hline Leptomastidea abnormis (Girault, 1915) & & $x$ & $\begin{array}{l}\text { CRC, CHN, EGY (Noyes \& Hayat, 1994; Thompson, 1955; Noyes, } \\
\text { 2000; Abd-Rabou, 2000; 2007; Zhang \& Xu, 2009) }\end{array}$ \\
\hline Mariola flava Noyes, 1980 & $x$ & & BRA, CRC (Noyes, 2010) \\
\hline Neastymachus delhiensis Subba Rao, 1957 & & $x$ & BAN (Noyes \& Hayat, 1994; Bhuiya et al., 1997) \\
\hline Microterys sp. & & $x$ & EGY (Noyes \& Hayat, 1994; Abd-Rabou, 2000; 2007) \\
\hline $\begin{array}{l}\text { Mucrencyrtus aclerdae (De Santis, 1972) } \\
\text { (= Aenasioidea aclerdae) }\end{array}$ & $\times$ & & BRA (De Santis, 1972; 1980; Culik \& Ventura, 2011) \\
\hline Trichomasthus sp. & $x$ & & MAS (Lim \& Pan, 1980) \\
\hline Mucrencyrtus insulanus Noyes, 1980 & $x$ & & TRI (Noyes, 1980) \\
\hline Neoprochiloneurus sp. & $x$ & & MAS (Lim \& Pan, 1980) \\
\hline Nikolskiella sp. & $x$ & & MAS (Lim \& Pan, 1980) \\
\hline Paraphaenaodiscus sp. & & $x$ & EGY (Noyes \& Hayat, 1994; Abd-Rabou, 2000) \\
\hline \multicolumn{4}{|l|}{ HYMENOPTERA } \\
\hline \multicolumn{4}{|l|}{ Encyrtidae } \\
\hline Prochiloneurus sp. & & $x$ & EGY (Noyes \& Hayat, 1994; Abd-Rabou, 2000) \\
\hline Pseudectroma sp. & & $x$ & - (Prinsloo, 1983) \\
\hline Zaplatycerus melvillei Compere, 1939 & & $\times$ & - (Noyes \& Hayat, 1994) \\
\hline Parachrysocharis javensis Girault, 1913 & & $\times$ & IND (Husain \& Khan, 1986) \\
\hline Pseudaphycus mundus Gahan, 1946 & & $x$ & BAR (Alam, 1972) \\
\hline Rhopus nigroclavatus (Ashmead, 1902) & & $\times$ & $\begin{array}{l}\text { EGY, IND (CIBC, 1976; Hayat, 1981; Hayat, 1986; IIBC, 1992; Noyes } \\
\& \text { Hayat, 1994; Abd-Rabou, 2000; 2007) }\end{array}$ \\
\hline $\begin{array}{l}\text { Rhopus mymaricoides Compere, } \\
\text { Subba Rao \& Kaur, } 1960\end{array}$ & & $\times$ & $\begin{array}{l}\text { IND (Herting, 1972; Shafee et al., 1975; Trjapitzin, 1989; IIBC, 1992; } \\
\text { Noyes \& Hayat, 1994; Hayat, } 1986 \text { 2006) }\end{array}$ \\
\hline Rhopus aligarhensis Shamim \& Shafee, 1989 & & $\times$ & $\begin{array}{l}\text { ETH (Prinsloo, 1978; Prinsloo \& Annecke, 1983; Noyes \& Hayat, } \\
\text { 1994) }\end{array}$ \\
\hline Rhopus sp. & & $\times$ & EGY (Herting, 1972; Noyes \& Hayat, 1994; Abd-Rabou, 2000; 2007) \\
\hline \multicolumn{4}{|l|}{ Signiphoridae } \\
\hline Chartocerus subaeneus (Förster, 1878) & & $\times$ & EGY (Abd-Rabou, 2000; 2007) \\
\hline Chartocerus fimbriae Hayat, 1970 & & $\times$ & IND (Hayat \& Subba Rao, 1986) \\
\hline Chartocerus ranae Subba Rao, 1957 & & $\times$ & IND (Hayat \& Subba Rao, 1986) \\
\hline \multicolumn{4}{|l|}{ Pteromalidae } \\
\hline Promuscidea sp. & $\times$ & & MAS (Lim \& Pan, 1976) \\
\hline
\end{tabular}

Note. Species of studied scale insects, prey or host of natural enemies: A (Aclerda takahashii), $S$ (Saccharicoccus sacchari). Countries mentioned: AFG (Afghanistan); AUS (Australia); BAN (Bangladesh); BAR (Barbados); BRA (Brazil); BER (Bermuda); BOL (Bolivia); CHN (China); COL (Colombia); CUB (Cuba); CRC (Costa Rica); EGY (Egypt); ETH (Ethiopia);FIJ (Fiji); USA (United States of America); GEO (Georgia); GRN (Grenada); GUY (Guyana); IND (India); JAM (Jamaica); JPN (Japan); MAD (Madagascar); MAS (Malaysia); MEX (Mexico); NCA (Nicaragua); NEP (Nepal); PER (Peru); PHI (Philippines); SRI (Sri Lanka); THA (Thailand); TRI (Trinidad \& Tobago); TUR (Turkey);VEN (Venezuela); - Countries not reported in the works.

\section{Appendix B}

\section{Information about the material examined}

\section{Anagyrus saccharicola}

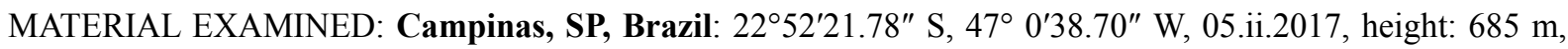
ex. S. sacchari about $S$. officinarum, $\left(6+\right.$ and $\left.60^{\text {}}\right)$ mounted on entomological pins. Col. Cruz, M.A. (Det. VAC).

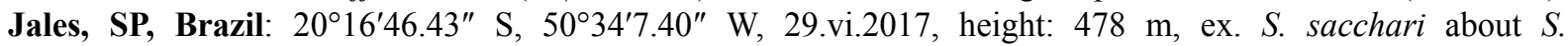
officinarum, (33 $q$ and $15 \delta^{\Uparrow}$ ) mounted on entomological pins. Col. Cruz, M.A. (Det. VAC). Jaboticabal, SP, Brazil: $21^{\circ} 17^{\prime} 14.62^{\prime \prime} \mathrm{S}, 48^{\circ} 18^{\prime} 35.16^{\prime \prime} \mathrm{W}, 25 . \mathrm{v} .2017$, height: $605 \mathrm{~m}$, ex. S. sacchari about $S$. officinarum, (1 () mounted on entomological pins. Col. Cruz, M.A. (Det. VAC). $21^{\circ} 18^{\prime} 34.70^{\prime \prime}$ S, 48 $18^{\prime} 25.92^{\prime \prime}$ W, 29.v.2017, height: $605 \mathrm{~m}$, ex. S. sacchari about S. officinarum, (4 + and $\left.1 \mathrm{O}^{\lambda}\right)$ mounted on entomological pins. Col. Cruz,

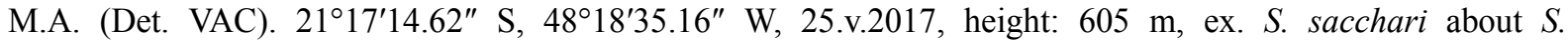
officinarum, $\left(9 \circ\right.$ and $\left.13{ }^{\top}\right)$ ) mounted on entomological pins. Col. Cruz, M.A. (Det. VAC). $21^{\circ} 13^{\prime} 47.41^{\prime \prime}$ S,

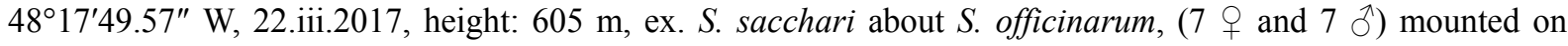

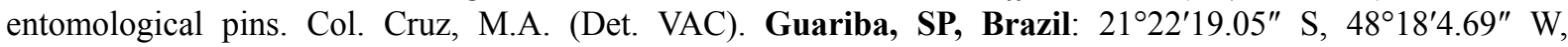
29.v.2017, height: $618 \mathrm{~m}$, ex. S. sacchari about $S$. officinarum, $\left(4+9\right.$ and $\left.1 \delta^{\Uparrow}\right)$ mounted on entomological pins. Col. Cruz, M.A. (Det. VAC). Fernandópolis, SP, Brazil: 20¹3'40.63" S, 50²0'32.85" W, 29.iii.2017, height: $535 \mathrm{~m}$, ex. S. sacchari about S. officinarum, $\left(2+\right.$ and $\left.1{ }^{\top}\right)$ mounted on entomological pins. Col. Cruz, M.A. (Det. 
VAC). Votuporanga, SP, Brazil: 20²1'47.87" S, 50 4'34.26" W, 29.vi.2017, height: 525 m, ex. S. sacchari about $S$. officinarum, $\left(\begin{array}{ll}5 & \sigma^{\prime}\end{array}\right)$ mounted on entomological pins. Col. Cruz, M.A. (Det. VAC). Nova Aliança, SP, Brazil: $21^{\circ} 2^{\prime} 57.71^{\prime \prime}$ S, 49³3'2.40" W, 28.vi.2017, height: 464 m, ex. S. sacchari about $S$. officinarum, (2 $q$ and 3 今) mounted on entomological pins. Col. Cruz, M.A. (Det. VAC).

\section{Mucrencyrtus aclerdae}

MATERIAL EXAMINED: Jaboticabal, SP, Brazil: $21^{\circ} 15^{\prime} 30.08^{\prime \prime}$ S, 48¹8'17.19" W, 07.ix.2016, height: 605 m, ex. A. takahashii about $S$. officinarum, (7 + ) mounted on entomological pins. Col. Cruz, M.A. (Det. VAC). $21^{\circ} 13^{\prime} 57.33^{\prime \prime}$ S, 48 $8^{\circ} 18^{\prime} 8.38^{\prime \prime}$ W, 21.x.2016, height: 605 m, ex. A. takahashii about $S$. officinarum, (1 9 ) mounted

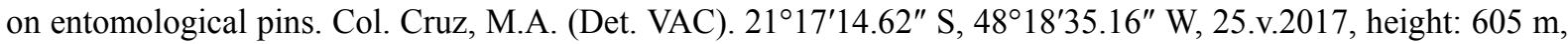
ex. A. takahashii about $S$. officinarum, (21 $q$ and 8 ) mounted on entomological pins. Col. Cruz, M.A. (Det. VAC). $21^{\circ} 17^{\prime} 13.09^{\prime \prime} \mathrm{S}, 48^{\circ} 18^{\prime} 34.24^{\prime \prime} \mathrm{W}, 26 . i v .2017$, height: $605 \mathrm{~m}$, ex. A. takahashii about S. officinarum, (3 ${ }^{\circ}$ and $60^{\text {) }}$ ) mounted on entomological pins. Col. Cruz, M.A. (Det. Costa, V.A). São Carlos, SP, Brazil: $22^{\circ}$

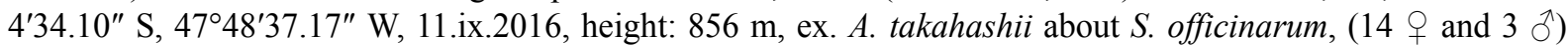

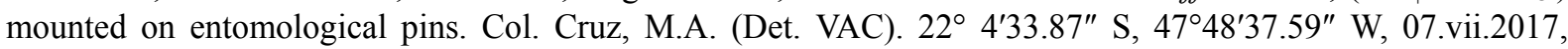
height: $856 \mathrm{~m}$, ex. A. takahashii about S. officinarum, (47 9 and 13 đ) mounted on entomological pins. Col. Cruz, M.A. (Det. VAC). Votuporanga, SP, Brazil: 20²1'47.87" S, 50 4'34.26”W, 07.vii.2017, height: 525 m, ex. A. takahashii about S. officinarum, (47 9 and $\left.13{ }^{\lambda}\right)$ mounted on entomological pins. Col. Cruz, M.A. (Det. VAC). Fernandópolis, SP, Brazil: $20^{\circ} 13^{\prime} 40.63^{\prime \prime}$ S, 50²0'32.85" W, 29.iii.2017, height: 535 m, ex. A. takahashii about $S$. officinarum, (13 $\odot$ and $\left.3{ }^{\Uparrow}\right)$ mounted on entomological pins. Col. Cruz, M.A. (Det. VAC). Pindorama, SP, Brazil: $21^{\circ} 13^{\prime} 14.54^{\prime \prime}$ S, 48 54'21.49" W, 28.vi.2017, height: 527 m, ex. A. takahashii about S. officinarum, (3 + ) mounted on entomological pins. Col. Cruz, M.A. (Det. VAC).

\section{Mariola flava}

MATERIAL EXAMINED: Jaboticabal, SP, Brazil: $21^{\circ} 17^{\prime} 13.09^{\prime \prime}$ S, 48¹8'34.24" W, 26.iv.2017, height: 605 m, ex. A. takahashii about $S$. officinarum, $\left(6 \circ\right.$ and $\left.1{ }^{\lambda}\right)$ mounted on entomological pins. Col. Cruz, M.A. (Det. VAC). Fernandópolis, SP, Brazil: 20¹3'40.63" S, 50²0'32.85" W, 29.iii.2017, height: 535 m, ex. A. takahashii about $S$. officinarum, $\left(13 q\right.$ and $\left.2{ }^{\top}\right)$ mounted on entomological pins. Col. Cruz, M.A. (Det. VAC).

\section{Hambletonia}

MATERIAL EXAMINED: Jales, SP, Brazil: 20¹6'46.43" S, 50³4'7.40" W, 29.vi.2017, height: 478 m, ex. S. sacchari about $S$. officinarum, (1 + ) mounted on entomological pins. Col. Cruz, M.A. (Det. VAC).

\section{Cheiloneurus}

MATERIAL EXAMINED: Fernadópolis, SP, Brazil: 20¹3'40.63" S, 50²0'32.85" W, 29.iii.2017, height: 535 $\mathrm{m}$, ex. A. takahashii about $S$. officinarum, $\left(2+9\right.$ and $\left.10^{\lambda}\right)$ mounted on entomological pins. Col. Cruz, M.A. (Det.

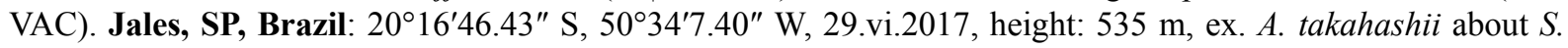
officinarum, (2 +) mounted on entomological pins. Col. Cruz, M.A. (Det. VAC).

\section{Eurytoma}

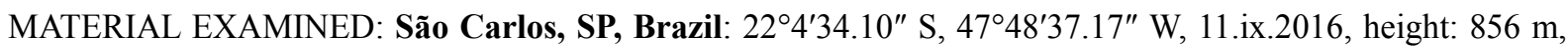
ex. A. takahashii about S. officinarum, (1 +) mounted on entomological pins. Col. Cruz, M.A. (Det. VAC). $22^{\circ}$ 4'33.87" S, 47²48'37.59" W, 11.ix.2016, height: 856 m, ex. A. takahashii about S. officinarum officcinarum, (1 ㅇ and $8{ }^{\Uparrow}$ ) mounted on entomological pins. Col. Cruz, M.A. (Det. VAC).

\section{Rhinoleucophenga obesa}

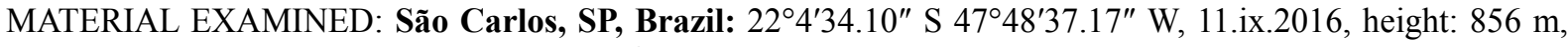
ex. A. takahashii about $S$. officinarum, (2 + ) mounted on entomological pins. Col. Cruz, M.A. (Det. GPI).

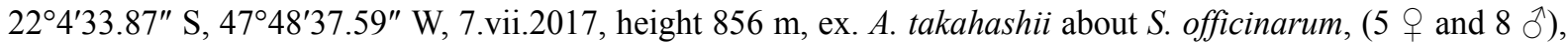
mounted on entomological pins. Col. Cruz, M.A. (Det. GPI).

\section{Diadiplosis}

MATERIAL EXAMINED: Jaboticabal, SP, Brazil: $21^{\circ} 18^{\prime} 34.70^{\prime \prime}$ S, 48 $18^{\prime} 25.92^{\prime \prime}$ W, 10.iv. 2017, height: 605 m, ex. S. sacchari about $S$. officinarum, $\left(4+\right.$ and $\left.90^{1}\right)$ mounted on permanent blades. Col. Cruz, M.A. (Det.

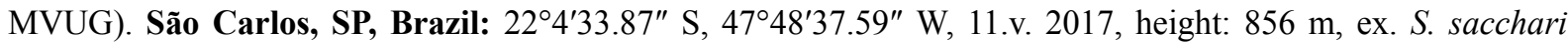
about $S$. officinarum, (1 specimen) mounted on permanent blades. Col. Cruz, M.A. (Det. MVUG). 


\section{Megaselia}

MATERIAL EXAMINED: Jaboticabal, SP, Brazil: 21¹7'14.62" S, 48¹8'35.16" W, 11.iii. 2017, height: 605 m, ex. $S$. sacchari about $S$. officinarum, (1 +$)$ mounted on permanent blades. Col. Cruz, M.A. (Det. GP).

\section{Hyperaspis}

MATERIAL EXAMINED: Jaboticabal, SP, Brazil: 21¹7'14.62" S, 48¹8’35.16" W, 25.v.2017, height: 605 m, ex. S. sacchari about $S$. officinarum, (2 + ) mounted on entomological pins. Col. Cruz, M.A. (Det. LMA). São Carlos, SP, Brazil: 21 ${ }^{\circ} 53^{\prime} 45.18^{\prime \prime} \mathrm{S}, 47^{\circ} 51^{\prime} 58.10^{\prime \prime} \mathrm{W}, 25 . \mathrm{v} .2017$, height: $856 \mathrm{~m}$, ex. S. sacchari about $S$. officinarum, (1 9 ) mounted on entomological pins. Col. Cruz, M.A. (Det. LMA).

\section{Copyrights}

Copyright for this article is retained by the author(s), with first publication rights granted to the journal.

This is an open-access article distributed under the terms and conditions of the Creative Commons Attribution license (http://creativecommons.org/licenses/by/4.0/). 